\title{
HANS KELSEN A ZALOŽENÍ ČESKOSLOVENSKA
}

\section{THOMAS OLECHOWSKI}

\begin{abstract}
Hans Kelsen and the Formation of Czechoslovakia
Following the Treaty of Trianon from 1920, the Hungary-Czechoslovak Mixed Arbitral Tribunal was established as a body resolving issues which arose from the annexation of the previously Hungarian territories to the newly-formed Czechoslovakia. A central question of numerous disputes was whether the Treaty's protective provisions applied to Hungarian nationals, now living in annexed Czechoslovakian territories, whose property was confiscated by the state. The Czechoslovakian government presented several documents in support of its interpretation, among them Kelsen's 'Opinion on the question of the genesis of the Czechoslovak State and Czechoslovak citizenship'. In his work, Kelsen presented his theoretical views regarding the formation of the state and then applied them to the formation of Czechoslovakia. A state, according to Kelsen, comes to existence when there is a sovereign law, which is effective in certain personal and territorial jurisdiction, i.e. the state must have its own set of enforceable rules, by which its citizen abide by. International recognition, on the other hand, plays no role whatsoever. Applying his theory, Kelsen concluded, that Czechoslovakia as a sovereign state was formed on the 28th of October 1918, when the 'Czechoslovak declaration of independence' (as the first constitution), was proclaimed. Therefore, all Hungarian nationals, who were Czechoslovakian citizens according to the Czechoslovakian law passed after that date, remained as such until they opted otherwise under the Treaty of Trianon, which meant that they could not count themselves as Hungarians at the time the Treaty was signed and as a result, the provision regarding the banning of any confiscation did not apply to them. Even though these arguments were refused by the Tribunal in 1931, Kelsen's far-reaching theoretical ideas dealing with the formation of the state were not forgotten and remain relevant to this date.
\end{abstract}

Keywords: Treaty of Trianon, opinion on the question of the genesis of the Czechoslovak State and Czechoslovak citizenship, Hungary-Czechoslovak mixed arbitral tribunal, formation of a state, formation of Czechoslovakia, confiscation

Klíčová slova: Trianonská smlouva, stanovisko k otázce vzniku Československého státu a československého občanství, československo-mad'arský rozhodčí soud, založení státu, založení Československa, konfiskace

DOI: $10.14712 / 23366478.2017 .17$

\section{OKOLNOSTI}

Wilhelm Fodor bydlel v malém městě poblíž soutoku řek Ipel’u a Dunaje, které bylo v němčině označováno jako „Eipelschlag“, v mad’arštině jako „Ipolyság“ a ve slovenštině jako „Ipolské Šiahy“. ${ }^{1}$ Do roku 1918 patřilo město do župy Hont Uher-

1 Uvedené okolnosti jsou převzaty z oficiálních publikací Stálého dvora mezinárodní spravedlnosti / Permanent Court of International Justice (PCIJ), Series C, No. 68 (1933), s. 32.

Dostupné z: http://www.icj-cij.org/pcij. 
ského království a bylo sídlem stejnojmenného „okresu“ (na něž byly uherské župy rozčleněny), který Fodor řídil. Dne 27. května 1919 bylo toto město anektováno Československem. Fodorův automobil i jeho rozsáhlá sbírka zbraní byly československým státem pro veřejné účely bez odškodnění zkonfiskovány. Poté, co byla dne 4. června 1920 podepsána Trianonská smlouva², zvolil si Fodor v souladu se článkem 63 této smlouvy mad'arské státní občanství.

Zmiňovaná smlouva v zásadě předvídala, že osoby, které měly do roku 1918 mad’arské státní občanství, „ipso facto“ získaly státní občanství toho státu, ke kterému obec, v níž měly domovské právo, nyní patřila (čl. 61). Výše uvedený článek 63 jim však umožňoval zvolit si státní občanství toho státu, jehož domovské právo měly předtím. ${ }^{3}$

Trianonská smlouva zároveň v článku 250 zaručovala všem mad’arským státním př́slušníkům $\mathrm{v}$ rámci určitých hranic svobodu jejich majetku a zakazovala konfiskace a likvidaci vítěznými mocnostmi. Fodor tudíž dne 26. února 1925 zažaloval Československou republiku před československo-mad’arským rozhodčím soudem, který byl zř́zen dle článku 239 Trianonské smlouvy. Tento soud se skládal z jednoho soudce jmenovaného mad'arskou stranou, z jednoho soudce jmenovaného československou stranou, dále pak ze dvou soudců, které delegoval Stálý dvůr mezinárodní spravedlnosti, a z jednoho ve shodě jmenovaného předsedy. ${ }^{4}$

Fodor nebyl jediný, kdo se v této záležitosti obrátil na soud; rozhodčí soud se musel zabývat celou řadou podobných př́padů. Mimo jiné se $\mathrm{k}$ němu obrátilo několik dědiců, kteří protestovali proti konfiskaci jimi nárokovaného dědictví v hodnotě více než 30000 korun v kdysi uherském městě Eperjes, nyní Prešov v Československu. I zde spočíval problém v tom, že někteří dědicové se pro mad'arské státní občanství rozhodli teprve až po konfiskaci. Podle právního názoru Československa byli proto - tak jako Wilhelm Fodor - v okamžiku konfiskace československými státními př́slušníky. Článek 250 Trianonské smlouvy na ně tudíž nebylo možné aplikovat a československo-mad’arský rozhodčí soud nebyl kompetentní v této věci rozhodovat. ${ }^{5}$

Československý zástupce před tímto rozhodčím soudem proto dne 2. ledna 1928 vznesl námitku proti kompetenci soudu a odůvodnil své stanovisko celou řadou posudkủ. Konkrétně se jednalo o tři memoranda, která vypracovali francouzští odborníci na mezinárodní právo Jules Basdevant a Gaston Jeze společně s řeckým diplomatem Nicola(o)sem Politisem a ve kterých se především vyjadřovali k jiným posudkům, které byly předtím vypracovány na pokyn mad’arské vlády, mimo jiné také k posudku Kelsenova žáka Josefa Laurenze Kunze. ${ }^{6}$ Žádost československého zástupce byla doplněna o „Po-

2 Trianonská smlouva ze dne 4. 6. 1920, Sbírka zákonů a vyhlášení Československého státu (dále jen: Sb.) 1922/102.

3 Tato ustanovení jsou prakticky stejného znění jako ustanovení článků 70 a 78 Saint-germainské smlouvy ze dne 10. 9. 1919, Staatsgesetzblatt für die Republik Österreich (dále jen: StGBl) 1920/303. K právu opce srov. podrobně KUNZ, J. L.: Die völkerrechtliche Option II. Breslau, 1928.

4 Soudní řád československo-mad'arského rozhodčího soudu ze dne 6. 11. $1922 \mathrm{Sb}$. 413, se změnami Sb. 1925/11, Sb. 1925/74 a Sb. 1931/118. Též publikováno v PCIJ, Series C, No. 68 (1933), s. 228-238.

5 PCIJ, Series C, No. 68 (1933), s. 30 a násl. Trianonská smlouva neobsahovala žádné ustanovení o tom, který stát by měl rozhodovat o platnosti využití práva opce; srov. KRAMER, A.: Die Staatsangehörigkeit der Altösterreicher und Ungarn nach den Friedensverträgen. Wien, 1926, s. 44.

6 A sice posudek ke článku 250 Trianonské smlouvy ze dne 9. 4. 1927, posudek k československé národnosti ze dne 16. 2. 1927 a nedatovaný posudek o dopadech založení státu: PCIJ, Series C, No. 68 (1933), 
sudek k otázce vzniku československého státu a československého státního občanstvi““ od Hanse Kelsena ${ }^{7}$ ze dne 1. listopadu 1927.

\section{KELSENU゚V POSUDEK}

Jak už je pro Kelsena typické, předchází jeho řešení hmatatelného právního problému téměř stejně dlouhý úvod z oblasti teorie práva. Způsob, jakým Kelsen svůj posudek vypracoval, mohl samozřejmě pramenit také ze skutečnosti, že Kelsen v této době ještě není odborníkem na mezinárodní právo v pravém slova smyslu. Jak sám později píše ${ }^{8}$ do roku 1930, kdy začal přednášet na katedře mezinárodního práva v Kolíně a později, v roce 1936 v Praze, ${ }^{9}$ se pozitivním mezinárodním právem téměř nezabýval. Jeho silnou stránkou byla právě oblast teorie práva, v níž se díky své monografii „Das Problem der Souveränität und die Theorie des Völkerrechts“ (Problém suverenity a teorie mezinárodního práva, pozn. překl.) z roku 1920 stal průkopníkem. ${ }^{10}$ Kelsenovy úvahy z teorie práva jsou v jeho posudku z roku 1927 proto z převážné části shrnutím tezí z jeho knihy, na kterou také opakovaně odkazuje. Jinak než ve své knize se ovšem vyhýbá jakékoliv polemice a pokouší se přesvědčit i ty čtenáře, kteří nesdílejí všechny jeho teoretické názory, že konečný výsledek je správný. ${ }^{11}$

\section{A. VZNIK STÁTU A STÁTNÍ ÚZEMÍ ČSR}

V první části se Kelsen zabývá otázkou, za jakých podmínek může vůbec vzniknout stát, a na úvod konstatuje, že se jedná o otázku, která může být zodpovězena pouze na základě pozitivního mezinárodního práva. ${ }^{12}$ Již toto je pozoruhodné zjištění,

s. 39-71. Mad’arskou stranou předložené posudky neexistují v tištěné podobě, jejich obsah lze pouze nepřímo vydedukovat. Basdevant se později (1949-1952) stal předsedou Mezinárodního soudního dvora; Jeze se v roce 1929 stal členem vydavatelského grémia časopisu „Internationale Zeitschrift für Theorie des Rechts“ (Mezinárodní časopis pro teorii práva, pozn. překl.) založeného Kelsenem společně s Františkem Weyrem.

7 PCIJ, Series C, No. 68 (1933), s. 71-102. Posudek byl vydán také jako samostatný výtisk (Praha 1927) a byl i přeložen do francouzštiny (KELSEN, H.: La naissance de l'Etat et la formation de sa nationalité. Les principes: leur application au cas de la Tchécoslovaquie. Revue de droit international, č. 3/1929, s. 613-641); z důvodu snazší př́ístupnosti po zveřejnění je (jako KELSEN, H.: Posudek) následně citován v oficiálních dokumentech Stálého dvora mezinárodní spravedlnosti.

8 KELSEN, H.: Autobiographie. Typoskript, Berkeley, 1947, s. 35. In JESTAEDT, M. (ed.): Hans Kelsen Werke I. Tübingen, 2007, s. 77.

9 K tomu OLECHOWSKI, T. - BUSCH, J.: Hans Kelsen als Professor an der Deutschen Universität Prag. Biographische Aspekte der Kelsen-Sander-Kontroverse. In MALÝ, K. - SOUKUP, L. (eds.): Československé právo a právní věda v meziválečném období 1918-1938 a jejich místo v Evropě. Praha, 2010, s. 1106-1134.

10 Viz ocenění tohoto díla SILVERMAN, P.: Souveränität als Voraussetzung juridischen Denkens und als Kristallisationspunkt politischer Selbstbindung. In JESTAEDT, M. (ed.): Hans Kelsen Werke IV. Tübingen, 2013, s. 249-262.

11 Na tomto místě je nutné poukázat na skutečnost, že Kelsen byl krátce předtím požádán ještě v jednom případě o posudek ohledně otázek státního občanství, a sice ve zvláštním případě knížete Alberta von Thurn und Taxis: KELSEN, H.: Gutachten zur Frage der österreichischen Staatsbürgerschaft des Fürsten Thurn und Taxis. Zagreb, 1924. Tento př́pad se však nijak nepodobá autorem zkoumanému př́padu.

12 KELSEN, H.: Posudek, s. 71. Srov. také KELSEN, H.: Principles of International Law. New York, 1952, ND Clark, 2003, s. 258. 
nebot' implicitně vychází z primátu mezinárodního práva nad právem ústavním. Jak známo, uznává Kelsen z hlediska teorie práva obě možnosti - primát mezinárodního práva i primát ústavního práva - jako rovnocenné a pouze z ideologicky pacifistických důvodů náznakem favorizuje primát práva mezinárodního. ${ }^{13}$ Tím se nachází v rozporu s Verdrossem, který považuje za možný pouze primát práva mezinárodního, v neposlední řadě také proto, že teorie o primátu ústavního práva není schopna vysvětlit všechny právní otázky, jako např́íklad onu ohledně vzniku státu. ${ }^{14} \mathrm{~V}$ předmětném posudku sleduje tedy Kelsen linii Verdrossovu, nebot' i on cituje a prohlašuje, že pokus vysvětlit založení státu na základě primátu ústavního práva je „petitio principii““. 15

Vezmeme-li ovšem jako referenční rámec mezinárodní právo, nalezneme zde větu z oblasti obyčejového práva, podle níž ,stát vzniká, když jsou dány tři jeho prvky: území, národ a státní moc“. ${ }^{16}$ Protože Kelsen, jak známo, zastával názor, že stát je identický se svým právním řádem, korigoval tuto větu $\mathrm{v}$ tom smyslu, že stát je považován za „vzniklý, když se vytvoří relativně suverénní, to znamená pouze mezinárodnímu právnímu řádu podřizený nucený ráa, který bude účinný v určité teritoriální a personální oblasti působnosti““. ${ }^{17}$ Národ státu je v této souvislosti tedy ona „personální“ oblast působnosti, území státu ona ,teritoriální“. K obému se bude nutné ještě vrátit. Prozatím jde ale Kelsenovi o to, aby popsal prvek „účinnost“: Státní rád bude účinný tehdy, když se jím poddaní budou ř́́dit; jestli ho tím „,uznávaji““ či nikoliv, považuje za pouhou terminologickou, nepodstatnou otázku. Začátek procesu nabývání účinnosti může také nastoupit nejprve postupně, především hranice nového státu nemohou na začátku ještě existovat. $\mathrm{V}$ každém př́padě je však moment efektivity faktem, na který bezprostředně navazují právní důsledky. A aby nový stát mohl existovat také z právního hlediska, není nutné uznání ze strany již existujících států. ${ }^{18}$ Stát, protože je identický se svým právním řádem, nemůže tedy nikdy existovat jinak než z právního hlediska; „de facto stát“, jak je předpokládán určitými odvětvími nauky o mezinárodním právu, je z hlediska

13 KELSEN, H.: Das Problem der Souveränität und die Theorie des Völkerrechts. Beitrag zu einer reinen Rechtslehre. Tübingen, 1920, s. 314 a násl. In JESTAEDT, M. (ed.): Hans Kelsen Werke IV. Tübingen, 2013, s. 567 a násl.; KELSEN, H.: Allgemeine Staatslehre. 1925, ND Wien 1993, s. 128; KELSEN, H.: Principles of International Law. New York, 1952, ND Clark, 2003, s. 438.

14 VERDROSS, A.: Die Einheit des rechtlichen Weltbildes auf Grundlage der Völkerrechtsverfassung. Tübingen, 1923, s. 76-86; VERDROSS, A.: Die Verfassung der Völkerrechtsgemeinschaft. Wien, 1926, s. 18. Viz k tomu BERNSTORFF, J. G., VON: Kelsen und das Völkerrecht: Rekonstruktion einer völkerrechtlichen Berufsethik, s. 160. In WALTER, R. - JABLONER, C. - ZELENY, K. (ed.): Hans Kelsen und das Völkerrecht. Schriftenreihe des Hans Kelsen-Instituts 26. Wien, 2004, s. 143-167; WALTER, R.: Die Rechtslehren von Kelsen und Verdroß unter besonderer Berücksichtigung des Völkerrechts, s. 50. In WALTER, R. - JABLONER, C. - ZELENY, K. (ed.): Op. cit., s. 37-49.

15 KELSEN, H.: Posudek, s. 71. Srov. také KUNZ, J. L.: Op. cit., s. 110, který řešení otázek státního občanství považuje za možné pouze na základě právně historické „hypotézy primátu mezinárodního práva“.

16 KELSEN, H.: Posudek, s. 72.

17 KELSEN, H.: Posudek, s. 72. Cituje v této souvislosti VERDROSS, A.: Op. cit., s. 125 a násl.

18 V KELSEN, H.: Das Problem der Souveränität und die Theorie des Völkerrechts. Beitrag zu einer reinen Rechtslehre. Tübingen, 1920, s. 229 a násl. In JESTAEDT, M. (ed.), Hans Kelsen Werke IV. Tübingen, 2013, s. 448 a násl. sice Kelsen prohlašuje, že za předpokladu primátu mezinárodního práva je uznání nového státu zásadní. Není tím však myšleno uznání prostřednictvím souhlasných aktů vůle starých států. Uznání spíše probíhá „obecně, postupně prostřednictvím právního ustanovení mezinárodního práva [...], které stanovuje, za jakých podmínek stát jako takový z hlediska mezinárodního práva [...] existuje." Souhlasně KUNZ, J. L.: Op. cit., s. 111. 
ryzí nauky právní věcí nemožnou. ${ }^{19}$ Taktéž není možné, aby nový stát vznikl tím, že s ním bude uzavřena nějaká smlouva: Vždyt's kým bychom chtěli takovouto smlouvu podepsat, když ne se zástupci již existujícího státu?20

Kelsen se tímto - aniž by to prímo vyslovil - připojuje ke klíčovému rozhodnutí československého Nejvyššího správního soudu ze dne 16. ř́jna 1919, podle něhož stát může, dokonce musí vzniknout již předtím, než bude mezinárodně uznán; ${ }^{21}$ Kelsen přiostřuje a upřesňuje tento názor ale ještě v tom smyslu, že mezinárodnímu uznání odebírá veškerý konstitutivní účinek, zatímco Nejvyšší správní soud vychází ještě z toho, že stát se tímto aktem stává „osobou mezinárodního práva“, a tudíž očividně rozlišuje mezi vnitrostátní a mezinárodní právní subjektivitou - což by bylo z hlediska ryzí nauky právní absurdní. ${ }^{22}$

Kelsen ve svém posudku upozorňuje, že je nutné rozlišovat několik různých druhů vzniku státu: Pokud mají starý a nový stát přesně tutéž personální a teritoriální oblast působnosti a $\mathrm{k}$ moci přišla cestou revoluce nová vláda, pak je starý stát identický se státem novým. ${ }^{23}$ - Tímto Kelsen přejímá panující terminologii mezinárodního práva; tato samožrejmě není z hlediska ryzí nauky právní účelná, logičtější by bylo hovořit o univerzálním právním nástupnictví nového státu. ${ }^{24}$ Tento terminologický problém je však v konečném důsledku druhořadý. Důležitější je, že Kelsen tento případ odlišuje od př́padu, kdy se stát rozpadne na několik jiných, malých států a neexistuje žádná kontinuita. Zde existují zvláštní mezinárodněprávní normy pro následnictví ohledně práv a povinností zaniklého státu, které však Kelsen v rámci svého posudku blíže nezmiňuje.

Kelsen spíše zkoumá pouze ta fakta, která vedla ke vzniku Československa: ${ }^{25}$ Zř́izení Československé národní rady v Paříži, kterou v průběhu roku 1918 uznalo několik spojeneckých mocností, jakož i ustanovení exilové vlády dne 14. ř́jina Kelsen považuje za akty „nejvyššího politického významu“, které však přece jen z právního hlediska k založení Československa nevedly. K založení došlo spíše zákonem ze dne 28. října 1918 o založení samostatného československého státu. ${ }^{26}$ Kelsen tento zákon označuje

19 KUNZ, J. L.: Op. cit., s. 112.

20 KELSEN, H.: Posudek, s. 75 a násl. Explicitně zde odkazuje na KELSEN, H.: Das Problem der Souveränität und die Theorie des Völkerrechts. Beitrag zu einer reinen Rechtslehre. Tübingen, 1920, s. 228 a násl. In JESTAEDT, M. (ed.), Hans Kelsen Werke IV. Tübingen, 2013, s. 487 a násl., kde je o problému uznání nových států podrobně pojednáno.

21 HILLGRUBER, Ch.: Die Aufnahme neuer Staaten in die Völkerrechtsgemeinschaft. Das völkerrechtliche Institut der Anerkennung von Neustaaten in der Praxis des 19. und 20. Jahrhunderts. Kölner Schriften zu Recht und Staat 6, Frankfurt a. M., 1998, s. 203 a násl.

22 Srov. především KELSEN, H.: Das Problem der Souveränität und die Theorie des Völkerrechts. Beitrag zu einer reinen Rechtslehre. Tübingen, 1920, s. 123. In JESTAEDT, M. (ed.): Hans Kelsen Werke IV. Tübingen, 2013 s. 385.

23 Podrobně k tomu tamtéž - Souveränität s. 238-240; HKW IV, s. 495-497.

24 To proto, že se jeví jako nelogické, když jsou dva (z hlediska ústavního práva) různé státy z hlediska práva mezinárodního identické, tedy vlastně jsou opět pouze jedním státem. Srov. MERKL, A.: Das Problem der Rechtskontinuität und die Forderung des einheitlichen rechtlichen Weltbildes. Zeitschrift für öffentliches Recht, sv. 5, 1926, s. 524 a OLECHOWSKI, T.: Kelsens Debellatio-These. Rechtshistorische und rechtstheoretische Überlegungen zur Kontinuität von Staaten. In JABLONER, C. u.a. (ed.): Gedenkschrift Robert Walter, Wien, 2013, s. 550 a násl.

25 KELSEN, K.: Posudek, s. 82 a násl.

26 Zákon o vytvoření samostatného československého státu, Sb. 1918/11. Toto odpovídalo názoru panujícímu v ČSR; srov. především Basdevant, Jeze a Politis v jejich posudcích: PCIJ, Series C, No. 68 (1933), 
za „první ústavu nového státu“, nebot’ tímto byla pro stát především ustanovena vláda a prostřednictvím přechodu práva byl také obnoven „materiální právní řád“. Kelsen zde argumentuje podobně, jak již učinil před devíti lety v posudku k mezinárodněprávnímu postavení Německého Rakouska: ${ }^{27}$ Dne 30. ř́ijna 1918, dva dny po založení Československa, přijalo také Provizorní národní shromáždění Německého Rakouska usnesení, kterým byla především ustanovena vláda, a došlo k převodu dosavadního práva. ${ }^{28}$ Již tehdy prohlásil Kelsen toto usnesení za ústavu, díky které revolučním způsobem vznikl nový stát Německé Rakousko. A již tehdy Kelsen zdůrazňoval, že stát Německé Rakousko vznikl stejným způsobem jako dva dny předtím Československo. ${ }^{29}$ Tento názor se však v roce 1919 při mírových jednáních v St. Germain nemohl prosadit, zde bylo na Německé Rakousko pohlíženo spíše jako na právního nástupce rakouského císařství, tak jako bylo Mad'arsko po roce 1918 považováno za identické s Uherskem před rokem $1918 .{ }^{30}$

Obzvláště důkladně zkoumá Kelsen ve svém posudku z roku 1927 otázku území státu, neboli, jeho terminologií, otázku teritoriální oblasti působnosti, kterou československý právní řád na počátku měl. Z celé řady dokumentů, jako např́iklad z Pittsburské dohody uzavřené mezi českými a slovenskými exilovými organizacemi, především ale také z textu samotného manifestu z 28. října 1918, který byl adresován ,čechoslováckému národu“, vyvozuje Kelsen, že od samého počátku bylo záměrem, že nový stát má zahrnovat nejen historické rakouské korunní země Čechy, Moravu a Slezsko, ale také Slovensko, tzn. „Slováky obývané území Uherska“. Ale právě i zde nezáleží ,,jen na záměru zrrídit nový řád [...], nýbrž na jeho účinnosti““.31 Faktické převzetí moci probíhalo obtížněji na Slovensku (a na Zakarpatské Rusi) než v zemích koruny české. ${ }^{32}$ V prosinci roku 1918 Československo mad’arské vládě blíže upřesnilo území, které si nárokovalo,

s. 55 a WEYR, F.: Das Verfassungsrecht der Tschechoslowakischen Republik. Zeitschrift für öffentliches Recht, zör. 2, 1921; ADAMOVICH, L.: Grundriss des tschechoslowakischen Staatsrechtes. Wien, 1929; KRAMER, A.: Op. cit., s. 32. Srov. také HILLGRUBER, CH.: Op. cit., s. 196, který na základě aktu ze dne 28. 10. 1918 zdůrazňuje, že ČSR měla ještě ,,před vykonáváním efektivní vlády na územích, která si nový stát nárokoval, omezené mezinárodní právní postavení“.

27 Tento posudek byl m. j. vydán v KELSEN, H.: Verfassungsgesetze der Republik Deutschösterreich I. Wien-Leipzig, 1919, s. 37-40. ND: In JESTAEDT, M. (ed.): Hans Kelsen Werke V. Tübingen, 2011, s. 61-64.

28 Usnesení Provizorního národního shromáždění Německého Rakouska ze dne 30. 10. 1918 StGBl. 1 o zásadním zřizení státní moci, srov. $§ 1, \S 16$.

29 KELSEN, H.: Die Verfassungsgesetze der Republik Deutschösterreich I. Wien-Leipzig, 1919, s. 38. In JESTAEDT, M. (ed.): Hans Kelsen Werke V. Tübingen, 2011, s. 61.

30 K tomu HILLGRUBER, CH.: Op. cit., s. 290-296 a 301.

31 KELSEN, H.: Posudek, s. 86.

32 Kelsen na tomto místě nemusí líčit osud německy mluvícího obyvatelstva v českých zemích: Toto sice nejprve na základě práva národů na sebeurčení založilo země „Německé Čechy“ a „Sudetsko“, které proklamovaly své připojení k Německému Rakousku, ovšem ČSR tato území anektovala ještě v průběhu roku 1918, proti čemuž Německé Rakousko pouze slavnostně protestovalo, vojenský odpor klást nemohlo; srov. německorakouský zákon ze dne 12. 3. 1919 StGB1. 175 o okupovaném státním území a jeho komentár̆ od Kelsena - KELSEN, H.: Die Verfassungsgesetze der Republik Deutschösterreich III. Wien - Leipzig, 1919, s. 20. In JESTAEDT, M. (ed.): Hans Kelsen Werke V. Tübingen, 2011, s. 354; SWANSON, J. C.: The Remnants of the Habsburg Monarchy: The Shaping of Modern Austria and Hungary, 1918-1922. New York, 2001, s. 30 a násl.; PERMAN, D.: The Shaping of the Czechoslovak State. Diplomatic History of the Boundaries of Czechoslovakia, 1914-1920. Leiden, 1962, s. 183 a násl. 
mj. měl být Dunaj až po soutok s Ipel’em stanoven jako hranice, takže také Ipolské Šiahy a samozřejmě i daleko za touto hranicí ležící Prešov měly patřit k Československu. „Za tuto hranici se“ dle Kelsena již koncem ledna „ozbrojená moc Mad’arska skutečně stáhla. [...] Na začátku února 1919 [se nacházelo] celé Slovensko s Bratislavou a Košicemi pod československou svrchovaností. “33

Kelsen tímto skutečné, proměnlivé válečné dění let 1918/19 značně zkracuje a líčí získání Slovenska z hlediska, kterým silně podporuje oficiální stanovisko Československa ${ }^{34}$, přičemž mad'arští historikové, ale nejen oni, celý průběh líčí mnohem diferencovaněji. ${ }^{35}$ Co se především oněch dvou na začátku jmenovaných měst, Ipolských Šiah a Prešova, týče, bylo již výše poukázáno na skutečnost, že Ipolské Šiahy byly Československem anektovány teprve v květnu 1919 - a v Prešově byla 16. června 1919 vyhlášena „Slovenská republika rad“", která se udržela necelé čtyři týdny, než se československým jednotkám podařilo toto území definitivně dobýt. ${ }^{36}$ Nesporným však zůstává, že Československo toto území, které mu bylo roku 1920 Trianonskou smlouvou přiřčeno ${ }^{37}$, minimálně v této době již několik měsíců efektivně ovládalo, a pouze tato skutečnost je očividně pro Kelsena rozhodující.

Při vyjednáváních o Trianonské smlouvě, jako vlastně při pařížských mírových jednáních vůbec, vystupovalo Československo každopádně jako „právní subjekt oprávněný uzavírat smlouvy“; 38 Kelsen z toho nutně vyvozuje, že Československo k tomuto okamžiku již existovalo, což by bylo nemožné, kdyby mělo své území, tedy konstitutivní státní prvek, získat teprve na základě Saint-germainské a Trianonské smlouvy. ${ }^{39}$ Sice je správné, že se Rakousko v článku 54 Saint-germainské smlouvy a Mad’arsko v článku 49 Trianonské smlouvy vzdaly veškerých práv a nároků na území za svými příslušnými hranicemi s Československem. Avšak právě co se Rakouska týče, prohlašuje Kelsen, že většinu tohoto území si Rakouská republika nikdy nenárokovala, proto se Rakousko těchto území ani nemohlo vzdát. $Z$ tohoto důvodu se Saint-germainská smlouva zakládá na dvojité fikci: Nejen, že na Rakouskou republiku nahlíží jako „na identickou se starou monarchií Rakouska“, nýbrž také předstírá, že Rakouská republika postupuje ČSR území, která si sama nikdy nenárokovala (na rozdíl od „staré monarchie“). ${ }^{40}$ V Mad’arsku byla sice situace potud jiná, protože se zde obecně, také z mad’arské strany předpoklá-

33 KELSEN, H.: Posudek, s. 89.

34 Srov. např. ADAMOVICH, L.: Op. cit., s. 17 a násl. a 34, podle něhož ČSR ,tato území skutečně převzala do své správy již od listopadu 1918 “.

35 Srov. např. ROMSICS, I.: The Dismantling of Historic Hungary: The Peace Treaty of Trianon, 1920. New York 2002, s. 67 a násl., ale také např. Američan SWANSON, J. C.: Op. cit., s. 62 a násl., nebo Slovák HRONSKÝ, M.: The Struggle for Slovakia and the Treaty of Trianon 1918-1920. Bratislava, 2001, s. 131 a násl.

36 ROMSICS, I.: Hungary in the Twentieth Century. Budapest, 1999, s. 106; STEINER, Z.: The Lights that failed. European International History 1919-1933. Oxford, 2005, s. 94.

37 K jednáním ohledně sporného území srov. PERMAN, D.: Op. cit., s. 222.

38 Trianonskou smlouvu, v níž je ČSR uváděna jako jedna ze ,spojených i sdružených mocností“, podepsali československý ministr zahraničí Edvard Beneš a vyslanec Štefan Osuský, dne 28. 1. 1921 ji schválilo československé Národní shromáždění a dne 19. 3. 1921 ji ratifikoval prezident Tomáš G. Masaryk.

39 Na mírové konferenci v Paříži byl tento bod sporný: Zatímco Francie vycházela z toho, že ČSR již existuje, zastávaly USA názor, že ČSR bude jako nový stát uznána teprve v rámci mírových jednání: HILLGRUBER, CH.: Op. cit., s. 197 a násl.

40 KELSEN, H.: Posudek, s. 92. 
dala identita starého s novým státem. ${ }^{41}$ Ale ani Mad'arsko nemohlo zmiňovaná území Československu postoupit, protože je v okamžiku podpisu smlouvy již nevlastnilo, nebo je nevlastnilo ani nikdy předtím.

Můžeme tedy shrnout, že ČSR již delší dobu před uzavřením Trianonské smlouvy ono území, které si nárokovala, také fakticky vlastnila, tedy suverénně ovládala. Kelsenova expertiza tedy plně odkazovala na otázku efektivity československé, resp. mad’arské vlády nad spornými územími; Rub v této souvislosti správně konstatoval, že Kelsen tímto efektivní dění prímo vyzdvihuje na úroveň zdroje mezinárodního práva. ${ }^{42}$ Kelsen se tímto staví nejen do opozice vůči názorům mad’arských právníků (kteří z pochopitelných důvodů zastávají jiný názor ${ }^{43}$ ), ale také vůči názoru svého vlastního žáka, odborníka na mezinárodní právo, Josefa Kunze, podle nichž ČSR sporná území nejprve pouze okupovala, avšak teprve po vstoupení Trianonské smlouvy v platnost nad těmito územími nabyla svrchovanost. ${ }^{44}$

\section{B. STÁTNÍ OBČANSTVÍ ČSR}

V Kelsenově posuzování důkazů je tímto však učiněn pouze první krok. V druhé, výrazně kratší části se zabývá právem na státní občanství a nejprve opět formuluje právní povahu tohoto. ${ }^{45}$ Stát sice nemůže existovat bez „poddaných“, tzn. bez lidí, kteří jsou podrobeni jeho právnímu řádu, může ale existovat bez státních př́slušníků: nebot' do jakých kategorií stát tyto poddané rozdělí, je věcí daného státu. Jsou to akty z oblasti pozitivního práva, které upravují nabytí a odnětí státního občanství, a to i v př́ípadě, kdy k nabytí státního občanství nově vzniklého státu dochází poprvé. Učinil-li tyto akty suverénní stát, musejí být považovány „za platné a závazné i z hlediska mezinárodního práva“". 46

Co se Československa týče, převzalo všeobecnou recepční klauzulí v $§ 2$ zákona ze dne 28. ř́ijna 1918 pouze pravidla pro nabytí a odnětí státního občanství; neexistovala však žádná pravidla pro to, kdo vůbec československým státním př́islušníkem je. Toto bylo upraveno teprve ústavním zákonem ze dne 9 . dubna $1920^{47}$, a to se zpětnou účinností. Dle tohoto zákona byly osoby, které měly nejpozději 1. ledna 1910 domovské právo v nějaké obci na území budoucího Československa, od 28. ř́ína 1918 státními př́slušníky Československa. Protože ČSR v roce 1920 již existovala, byla dle Kelsenova názoru k takovémuto kroku oprávněna.

41 KUNZ, J. L.: Op. cit., s. 119. Právě tomuto bodu odporoval oficiální jazykový úzus ČSR, který rozlišoval „Uhersko“ (před 1918) a „Mad’arsko“" (po 1918).

42 RUB, A.: Hans Kelsens Völkerrechtslehre. Versuch einer Würdigung. Wien - Zürich, 1995, s. 333.

43 Srov. BUZA, L.: Die Entstehung der ČSR im Lichte des Völkerrechts. Zeitschrift für Völkerrecht, sv. 13, 1924, a především právníci Barthélemy a Gidel citovaní v posudcích Basdevanta, Jeze a Politise, kteří vycházeli z toho, že Slovensko bylo ČSR postoupeno teprve „cesi“"ze dne 26. 7. 1921, zatímco Basdevant, Jeze a Politis zastávali názor, že ČSR vznikla aktem „osvobozeni““ a své území nabyla již v roce 1918: PCIJ, Series C, No. 68 (1933), s. 51 a násl.

44 Především, ale také KUNZ, J. L.: Op. cit., s. 118. Podle toho se okupace sice mohla opírat o dohodu o prŕíměří, nikoli však následná prohlášení ČSR, která tímto porušovala mezinárodní právo.

45 KELSEN, H.: Posudek, s. 95 a násl.

46 Tamtéž, s. 97.

47 Srov. 1920/236; srov. k tomu ADAMOVICH, L.: Op. cit., s. 46-49. 
Článek $61^{48}$ Trianonské smlouvy odporuje dle Kelsena výše uvedenému pouze zdánlivě; podle této smlouvy vykonávají osoby ,ipso facto“ státní občanství toho státu, který na území př́slušné domovské obce vykonává svrchovanost. Datum v tomto článku 61 uvedeno není, takže může být chápán tak, že potvrzuje ustanovení československého zákona, tedy že taktéž platí zpětně. I zde vidí Kelsen paralelu k Rakousku, zvláště když článek 70 Saint-germainské smlouvy obsahuje ustanovení téhož znění a ti občané, kteří měli předtím německorakouské státní občanství, se dle tohoto článku 70 stali československými státními občany a německorakouské státní občanství se zpětnou účinností pozbyli. ${ }^{49}$ Kdybychom článek 61 Trianonské smlouvy opravdu vykládali tak, že všichni Slováci pozbyli uherské státní občanství teprve až tímto ustanovením, bylo by to mimo jiné v rozporu se smlouvou na ochranu národnostních menšin, kterou ČSR ještě předtím se Spojenci podepsala a v níž smluvní strany vycházely z existence československých státních př́islušníků. ${ }^{50}$

Celkově tedy Kelsen dochází k tomuto závěru: „Nejen ty osoby, které nejpozději do 1. ledna 1910 nabyly domovské právo na území Čech, Moravy a Slezska, ale také na území Slovenska, jsou dle předpisů československého ústavního zákona ze dne 9. dubna 1920, které nijak neodporují všeobecnému mezinárodnímu právu a ustanovením Trianonské smlouvy, československými státními příslušníky. Ti z nich, kteří na základě článku 63 Trianonské smlouvy měli právo opce, byli až do okamžiku účinnosti prohlášení o opci československými státními př́ílušníky. ${ }^{\text {"51 }}$

I v tomto bodě se Kelsen odklání od Kunzova názoru, který vychází z toho, že osoby, které měly domovské právo na Slovensku, nabyly československé státní občanství až při vstupu smlouvy v platnost (26. července 1921). Tento předpoklad by podle Kunze platil i tehdy, kdyby byla anexe Slovenska zákonná již před vstupem Trianonské smlouvy v platnost; v tomto případě vytváří smlouva „fikci“, kterou jsou vázány především rozhodčí soudy, jež byly na základě této smlouvy založeny.

\section{III. ÚČINEK A VÝZNAM POSUDKU}

Výše uvedeným se dotýkáme praktického významu Kelsenova posudku. Svou expertizou podpořil postoj československé vlády, podle něhož osoby, které podaly žalobu před rozhočím soudem, byly v okamžiku jejich újmy na majetku československými státními př́islušníky, teprve po vykonání práva opce tohoto státního občanství

48 V KELSEN, H.: Posudek, s. 99, mylně označován za „§ 6“.

49 Na základě německorakouského zákona ze dne 5. 12.1918 StGB1. 91 získala státní občanství Německého Rakouska celá řada osob, které bydlely na územích, která si sice Německé Rakousko nárokovalo, efektivně je však ovládala ČSR. Na základě Saint-germainské smlouvy bylo těmto osobám, jak uvádí KELSEN, H.: Posudek, s. 99, německorakouské státní občanství se zpětnou účinností odňato.

50 Míněna je smlouva na ochranu národnostních a náboženských menšin, Sb. 1921/508, která byla dne 10.9. 1919 uzavřena v St. Germain (tedy v tentýž den a na tomtéž místě jako smlouva s Rakouskem) mezi čelními mocnostmi spojenými i sdruženými na straně jedné a ČSR na straně druhé.

51 KELSEN, H.: Posudek, s. 102. Jeho výsledek tedy odpovídá výsledku, k němuž ve svém posudku došli Basdevant, Jeze a Politis: PCIJ, Series C, No. 68 (1933) 66, kteří především odmítají, že by opce mohla mít zpětnou účinnost (,rétroactif“). Také KRAMER, A.: Op. cit., s. 45, míní, že opce je účinná (teprve) okamžikem prohlášení opce. 
pozbyly a nabyly mad’arské státní občanství. Proto se nemohly odvolávat na ochrannou klauzuli článku 250 Trianonské smlouvy a ani se nemohly obrátit na československo-mad'arský rozhodčí soud.

Československo-mad’arský rozhodčí soud se ke Kelsenovu názoru nepřiklonil. Dne 21. prosince 1931 vydal dva mezitímní rozsudky (arrêtes interlocutoires), v nichž konstatoval, že optanti si své mad’arské státní občanství ,uchovali“ („,conservé“), pročež je rozhodčí soud v obou prrípadech oprávněn učinit meritorní rozhodnutí. 52

Československá vláda proti tomuto rozhodnutí vznesla 7. července 1932 námitku u Stálého mezinárodního soudního dvora v Den Haagu, ${ }^{53}$ svou námitku však 8. dubna 1933 před ústním projednáváním z neznámých důvodů stáhla. ${ }^{54}$ Bohužel se mi nepodařilo zrekonstruovat další osud procesních stran a především vysvětlit, proč vláda svou námitku stáhla.

Význam Kelsenova posudku však dalece přesahuje tyto jednotlivé prŕípady: Na jedné straně ukazuje, jak se Kelsenovi podařilo ze svých obecně právně teoretických úvah vyvodit konkrétní závěry pro pozitivní právo. Přitom je pozoruhodné, že jak pro Rakousko v roce 1918, tak pro Československo v roce 1927 vypracoval vždy posudek, v němž bylo založení těchto dvou států znázorňováno ve značných paralelách. Skutečnost, že se v obou př́ípadech se svými názory neprosadil, jeho tezím na významu nijak neubírá.

Ao. Univ.-Prof. Dr. Thomas Olechowski

Universität Wien, Institut für Rechts- und Verfassungsgeschichte

thomas.olechowski@univie.ac.at

PCIJ, Series C, No. 68 (1933), s. 29-32.

Tamtéž, s. 9-29.

44 Tamtéž, s. 278. 